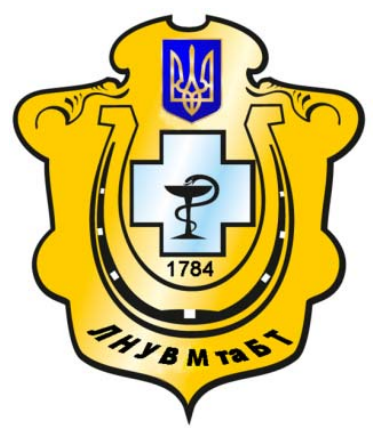

Науковий вісник Львівського національного університету ветеринарної медицини та біотехнологій імені С.3. Гжицького

Scientific Messenger of Lviv National University of Veterinary Medicine and Biotechnologies named after S.Z. Gzhytskyj

doi:10.15421/nvlvet7110

ISSN 2413-5550 print

ISSN 2518-1327 online

$\underline{\text { http://nvlvet.com.ua/ }}$

УДК 616:636.1:611.018.5:615.03

\title{
Вплив імуномодуляторів на показники клітинного імунітету лошат верхових порід
}

\author{
Я.П. Криця \\ Argo37@yandex.ru \\ Національний університет біоресурсів і природокористування Украӥни, \\ вул. Героїв Оборони, 11, м. Київ, 03041, Украӥна
}

\begin{abstract}
Для підтримання організму на достатньому фізіологічному рівні необхідно ефективне функціонування імунної системи, від якої залежить резистентність та імунна реактивність тварин. В наших дослідженнях у новонароджених лошат зрілими виявились показники клітинної ланки імунітету. При дослідженні лошат різного віку встановлено зниження гематологічних показників у тварин місячного віку.

Застосування імуномодуляторів запобігає виникненню імунодефіцитних станів у тварин. Введення їм імуномодуляторів нормалізуе T-систему імунітету, зокрема, у крові зростає кількість лейкоцитів, окремих популяиій лімфоцитів, особливо теофілінрезистентної субпопуляції T-хелперів, підвищується функиіональна активність лімфочитів.

Під виливом ріботану у лошат виявлена тендениіл до збільшення вмісту Т-лімфоцитів на 0,2 - 1,2\% (0,4 - 2,3\%) відповідно чистокровної та украӥнської верхових порід.

Результати досліджень вмісту T-хелперних та T-супресорних клітин показали, що при застосуванні імуномодуляторів не тільки зростала кількість $T$-хелперів, але й вирівнювалося співвідношення $T-x / T-c$, яке виявилось найбільш оптимальним (1,9 од.) у лошат при введенні ріботану. Аналізуючи функиіональний стан T-лімфочитів при застосуванні імуномодуляторів виявлено вірогідне збільшення кількості Т-активних лімфоцитів у лошат чистокровної верхової породи більш ніж в 2 рази $(P<0,01)$ та тенденцію до збільшення вмісту ичи клітин у лошат украйнської верхової породи. Стосовно $T$ термостабільних лімфоцитів, відзначаємо, щуо тенденція до найбільш оптимального рівня цих клітин встановлена у лошат при введенні ріботану (знаходиться в межах величин 3 -4\%). Збільшення кількості T-термостабільних клітин вище 4\% свідчить про підвищення сили супресорної популяції Т-лімфочитів, щяо вказує на пригнічення активності T-хелперів, а відповідно і вироблення антитіл. Таким чином, застосування ріботану в дозі 1 мл/тварину протягом трьох діб призводить до збільшення на 1,4 - 4,5\% кількості лейкоцитів у крові лошат дослідних груп, порівняно з контрольними тваринами.

Під впливом ріботану у крові лошат підвищується клітинна (кількість Т-лімфоцитів на 0,4 - 2,3\%) та функціональна активність (T-активні лімфочити в 2,3 рази; $P<0,05)$ T-системи імунітету. Під впливом ииклоферону у крові лошат підвищується функиіональна активність T-системи імунітету (кількість T-активних лімфоцитів на 16,7 - 25\%; P < 0,05).

Ключові слова: імунітет, імуномодулятор, ріботан, циклоферон, Т-лімфоцити, В-лімфочити, кров, лошата, чистокровна верхова порода, украӥнська верхова порода.
\end{abstract}

\section{Влияние иммуномодуляторов на показатели клеточного иммунитета жеребят верховых пород}

\author{
Я.П. Крыця \\ Argo37@yandex.ru \\ Национальный университет биоресурсов и природопользования Украины, \\ ул. Героев Обороны, 11, Киев, 03041, Украина
}

Для поддержания организма на должном физиологическом уровне необходимо эффективное функционирование иммун-
ой системы, от которой зависит резистентность и иммунная реактивность животных. В наших исследованиях у ново-

Citation:

Krytsia, I.P. (2016). The influence of immunomodulators on the performance of cellular immunity at the foals of saddle breeds. Scientific Messenger LNUVMBT named after S.Z. Gzhytskyj, 18, 3(71), 45-49. 
рожденных жеребят зрельми оказались показатели клеточного звена иммунитета. При исследовании жеребят разного возраста установлено снижение гематологических показателей у животных месячного возраста.

Применение иммуномодуляторов предотвращуает возникновение иммунодефицитных состояний у животных. Введение им иммуномодуляторов нормализует T-систему иммунитета, в частности, в крови возрастает количество лейкоцитов, отдельных популяций лимфоцитов, особенно теофилинрезистентной субпопуляции Т-хелперов, повыциется функциональная активность лимфоцитов. Под влиянием риботана у жеребят выявлена тенденция к увеличению содержания Тлимфоцитов на 0,2 - 1,2\% (0,4 - 2,3\%) соответственно у чистокровной и украинской верховых пород.

Результаты исследований содержания T-хелперных и T-супрессорных клеток показали, что при применении иммуномодуляторов не только росло число $T$-хелперов, но и выравнивалось соотномение $T-x / T-c$, которое оказалось наиболее оптимальным (1,9 ед.) у жеребят при введении риботана.

Анализируя функциональное состояние Т-лимфоцитов при применении иммуномодуляторов выявлено достоверное увеличение количества T-активных лимфочитов у жеребят чистокровной верховой породы более чем в 2 раза (Р<0,01) и тендениию к увеличению содержания этих клеток у жеребят украинской верховой породы.

В отношении T-термостабильных лимфоцитов, отмечаем, что тенденция к наиболее оптимальному уровню этих клеток установлена у жеребят при введении риботана (находится в пределах величин 3 - 4\%). Увеличение количества Ттермостабильных клеток выше 4\% свидетельствует о повышении силь супрессорной популяции Т-лимфоцитов, что указывает на угнетение активности Т-хелперов, а соответственно и выработку антител. Таким образом, применение риботана в дозе 1 мл/гол. в течение трех суток приводит к увеличению на 1,4 - 4,5\% количества лейкоичтов в крови жеребят опытных групп в сравнении с контрольными животными. Под влиянием риботана в крови жеребят повышается клеточная (количество T-лимфоцчитов на 0,4 - 2,3\%) и функциональная активность (T-активные лимфоциты в 2,3 раза; Р<0,05) T-системы иммунитета. Под влиянием ичиклоферона в крови жеребят повышается функииональная активность Тсистемы иммунитета (количество T-активных лимфоцитов на 16,7-25\%; P<0,05).

Ключевые слова: иммунитет, иммуномодулятор, риботан, ичиклоферон, Т-лимфоцитьл, В-лимфоцитьл, кровь, жеребята, чистокровная верховая порода, украинская верховая порода.

\title{
The influence of immunomodulators on the performance of cellular immunity at the foals of saddle breeds
}

\author{
I.P. Krytsia \\ Argo37@yandex.ru \\ National University of life and environmental sciences of Ukraine, \\ Heroyiv Oborony Str., 11, Kyiv, 03041, Ukraine
}

To maintain a body at sufficient physiological level the effective functioning of the immune system, which determines the resistance and immune reactivity of animals, is necessary. In our studies in newborn foals indicators of cellular immunity were mature. During the studying of foals of all ages were established the reduction of hematological parameters in animals months of age.

The use of immunomodulators prevents the immunodeficiency in animals. Immunomodulators introduction for animals normalizes T-immune system, in particular, increases the number of leucocytes in the blood, lymphocytes of certain populations, especially teofilin-resistant subpopulation of T-helper cells, increases the functional activity of lymphocytes.

Under influence of ribotan revealed a trend to the increasing of T-lymphocytes by $0.2-1.2 \%(0.4-2.3 \%)$, respectively in Purebred Saddle and Ukrainian Saddle breeds. Results of the content of T-helper and T-suppressor cells in foals blood after ribotan administration showed that the use of immunomodulators not only increases the number of $T$-helper cells, but restores the ratio $T-h$ $/ T-S$, which returned to the optimal rate (1.9). Analyzing the functional status of T-lymphocytes during the application of immunomodulators was found the probable increase of the number of activated T-lymphocytes in Purebred Saddle foals more than 2-fold (P $<0.01)$ and trend to increase of these cells in Ukrainian Saddle foals. In relation to thermostable T-lymphocytes, was note that the trend to the most optimal level of these cells installed in foals after administration of ribotan (values within $3-4 \%$ ). The increasing in number of thermostable T-cells more than $4 \%$ indicates an increase power of suppressor T-cells population, indicating the inhibition of T-helper cells, and therefore the production of antibodies. Thus, the use of ribotan in dose of $1 \mathrm{ml} /$ animal for three days leads to an increasing in $1.4-4.5 \%$ of the number of leukocytes in the blood of experimental group of foals compared with control animals. Under influence of ribotan in the blood of foals increases cell (number of T-lymphocytes in $0.4-2.3 \%$ ) and functional activity (T-active lymphocytes in 2.3 times; $P<0.05)$ T-immune system. Under influence of cycloferon in the blood of foals increases the functional activity of T-immune system (the number of T-active lymphocytes in $16.7-25 \% ; P<0.05$ ). breeds.

Key words: immunity, immunomodulator, rybotan, cycloferon, $T$-cells, B-cells, blood, foals, Purebred Saddle, Ukrainian Saddle

\section{Вступ}

В теперішній час велике значення приділяється проблемі підвищення життєздатності, резистентності та кращого збереження молодняку тварин. Як відомо, для підтримання організму на достатньому фізіологічному рівні необхідне ефективне функціонування імунної системи, від якої залежить резистентність та імунна реактивність тварин.
У наших дослідженнях у новонароджених лошат зрілими виявились показники Т-клітинної ланки імунітету, а менш зрілими - показники В-системи імунітету. До такого ж висновку дійшли в своїх дослідженнях Г.Д. Каци, I.I. Гаранович (Kacy and Kojuda, 2003), Л.І. Коюда (Kojuda, 2000).

Синтез власних антитіл починається лише 3 двотижневого віку, однак до одного місяця він відбувається на низькому рівні. Слабка гуморальна відповідь 
на антигенну стимуляцію в цей період пов'язана, 3 одного боку, з наявністю в організмі молодих тварин материнських антитіл, які блокують антигени, що надходять, $з$ іншого - 3 недостатнім формуванням Всистеми імунітету, яка відповідає за синтез антитіл (Saliga and Vishhur, 2002). Повного розвитку імунна система досягає до піврічного віку. Саме тому важливо в період вікового зниження імунореактивності організму (1 місяць), тобто при виникненні вікових імунних дефіцитів, застосовувати методи фармакологічної імунокорекції шляхом використання імуномодуляторів.

Застосування імуномодуляторів запобігає виникненню імунодефіцитних станів у тварин. Введення їм імуномодуляторів нормалізує стан Т-системи імунітету, зокрема, у крові зростає загальна кількість лейкоцитів, окремих популяцій лімфоцитів, особливо теофілінрезистентної субпопуляції Т-хелперів, збільшується функціональна активність лімфоцитів (Kichun et al., 2001).

Незважаючи на надто важливе значення імуномодулюючих препаратів, вони не знайшли широкого застосування в тваринництві. Обмежені повідомлення про застосування такого препарату, як ріботан та відсутня інформація про використання циклоферону в тваринництві; в конярстві повідомлення про застосування цих препаратів не виявлено.

Таким чином, дослідження показників клітинного імунітету лошат під впливом імуномодуляторів для корекції імунного статусу організму $є$ актуальним i становить інтерес в науковому і практичному відношенні.

Мета роботи полягала в дослідженні показників клітинного імунітету лошат верхових порід під впливом імуномодуляторів.

Для досягнення поставленої мети поставлено завдання встановити вплив ріботану та циклоферону на показники клітинного імунітету лошат.

\section{Матеріал і методи досліджень}

Дослідження проводилися в умовах Деркульського кінного заводу №63 Біловодського району Луганської області на лошатах чистокровної верхової та української верхової порід.

Для проведення досліджень 3 лошат 14-добового віку за принципом аналогів формували контрольну та дві дослідні групи (по 10 голів в кожній групі). Всього обстежено 30 голів. Тваринам 1 дослідної групи вводили ріботан, 2 дослідної - циклоферон. Імуномодулятори ріботан і циклоферон вводили внутрішньом'язово у середню третину шиї один раз на добу у наступних дозах: ріботан - 1 мл/тварину три дні поспіль; циклоферон - 2 мл/тварину у вигляді 12,5\% розчину на $1,2,4,6,8$ добу. Тваринам контрольної групи вводили ізотонічний розчин натрію хлориду. Відбір крові проводили у лошат місячного віку.

Забір периферичної крові з яремної вени, ії стабілізація гепарином проводилися за загальноприйнятими методиками. Визначали наступні показники імуні- тету: відносну кількість у крові загальних Тлімфоцитів, кількість Т-хелперів і Т-супресорів, імунорегуляторний коефіцієнт, кількість Т-активних лімфоцитів, Т-термостабільних лімфоцитів (\%).

Отримані дані були оброблені методами варіаційної статистики з використанням пакету аналізу даних Microsoft Excel.

\section{Результати та їх обговорення}

Для аналізу стану клітинного імунітету під впливом препаратів проводили дослідження кількості Тзагальних, Т-активних, Т-термостабільних лімфоцитів, Т-хелперів та Т-супресорів, IРК.

Вміст Т-загальних лімфоцитів у крові лошат під впливом ріботану та циклоферону наведений на рис. 1.

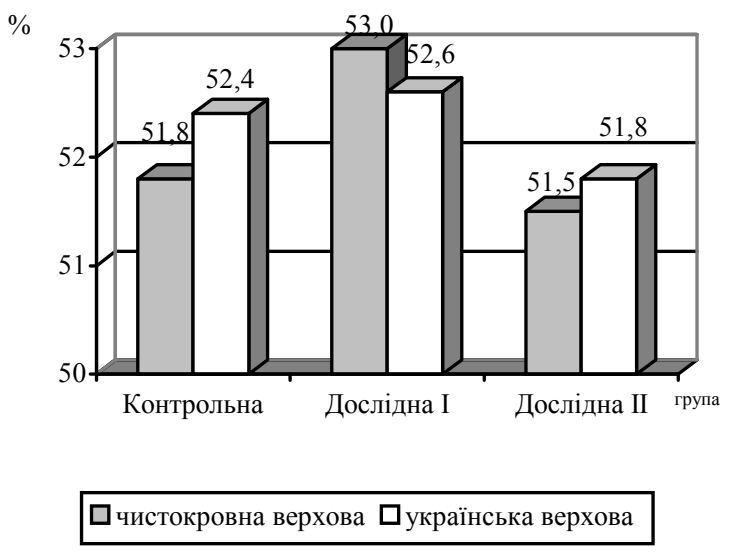

\section{Рис. 1. Відносна кількість Т-загальних лімфоцитів у крові лошат, \%}

Аналізуючи наведені на рис. 1 дані, видно, що вміст Т-загальних лімфоцитів був найвищим у крові лошат обох порід першої дослідної групи. У крові лошат, яким вводили ріботан, встановлена більша кількість Т-лімфоцитів на 0,2 - 1,2\% (0,4-2,3\%), а у крові тварин, яким застосовували циклоферон, кількість цих клітин виявилася навіть трохи нижчою, порівняно з кров'ю лошат контрольної групи.

При дослідженні вмісту теофілінрезистентних та теофілінчутливих лімфоцитів отримали такі результати (рис. 2).

Отримані результати вказують на вищий вміст Тхелперів у крові лошат української верхової породи в усіх досліджуваних групах. Слід також відзначити тенденцію до більшої кількості Т-х у крові лошат першої дослідної групи, порівняно з тваринами контрольної та другої дослідної груп.

Вміст Т-супресорів у крові лошат знаходився приблизно на однаковому рівні, лише у тварин чистокровної верхової породи контрольної групи встановлено вірогідно більшу на 6,2\% (38,8\%; Р < 0,05) кількість цих клітин, порівняно з українською верховою породою. 
$\%$

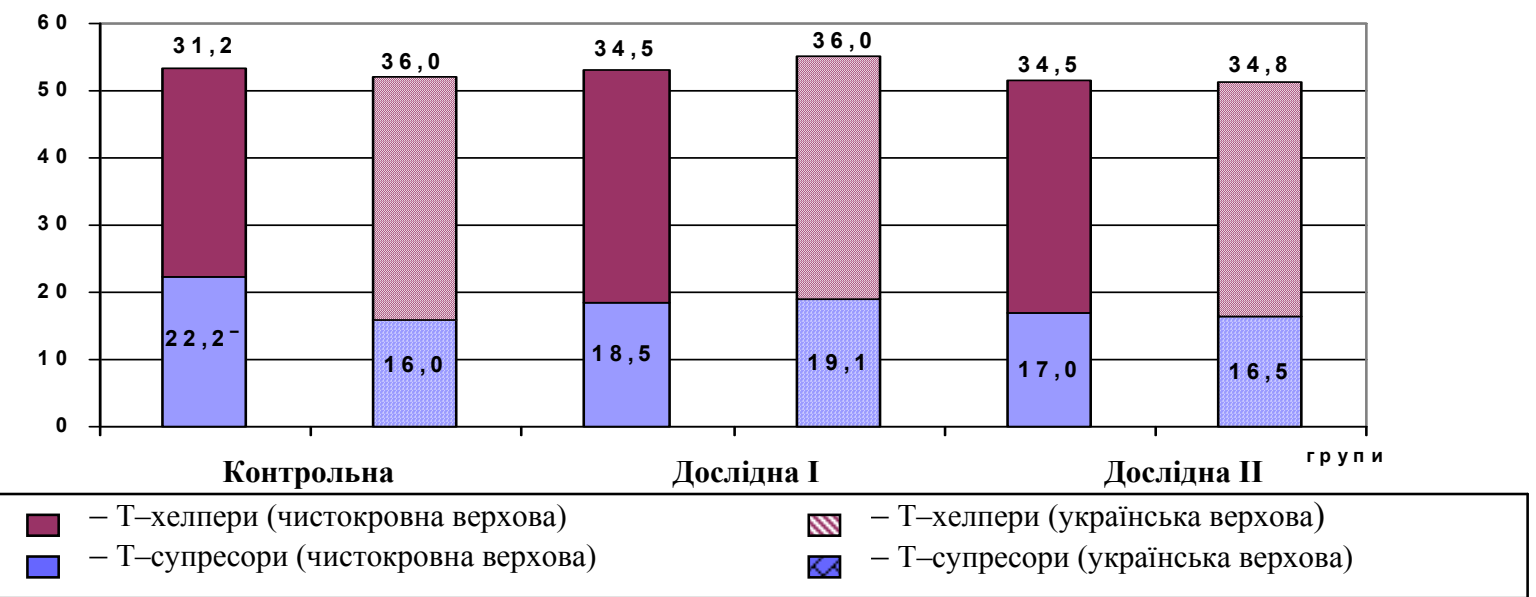

Рис. 2. Вміст T-хелперів та T-супресорів у крові лошат

Примітка: $\quad-\quad$ - $<0,05$ - між породами

Важливе значення для аналізу клітинного імунітету має визначення співвідношення між субпопуляціями Т-х і Т-c (IPК), яке наведено на рис. 3.

од.

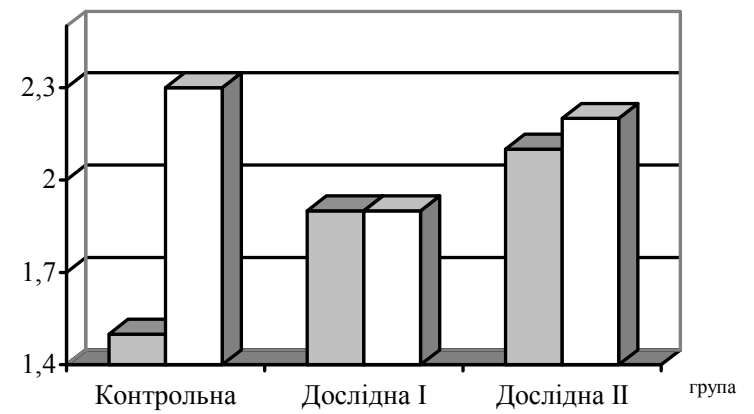

$\square$ чистокровна верхова $\square$ українська верхова

Рис. 3. ІРК крові лошат

Для нормальної імунної відповіді на 2 - 3 клітини T-хелперів повинна приходитись 1 клітина Тсупресорів. Якщо відбувається зсув IРК ліворуч (значення нижче 1,5$)$, то таке співвідношення $є$ характерним для імунодефіцитних станів, онкологічних захворювань.

Аналізуючи співвідношення $\mathrm{T}-\mathrm{x} / \mathrm{T}-\mathrm{c}$, слід відзначити, що тенденція до найбільш оптимального значення імунорегуляторного коефіцієнта встановлена у крові лошат першої дослідної групи (знаходився на рівні

1,9 од.). Збільшення IРК вище 2 од. свідчить про вищий рівень $\mathrm{T}-\mathrm{x}$, а відповідно в організмі виробляється більше антитіл, що може викликати аутоімунні захворювання. Зменшення IPК нижче 2 од. вказує на більшу кількість антигена, тобто відбувається недостатня імунна відповідь.

Функціональний стан Т-лімфоцитів визначали за вмістом Т-активних і Т-термостабільних лімфоцитів (табл. 1).
Отримані дані щодо вмісту Т-активних лімфоцитів вказують на вірогідне збільшення їх збільшення в 2,3 рази $(\mathrm{P}<0,01)$ у крові лошат чистокровної верхової породи першої дослідної групи, та в 2,1 рази $(\mathrm{P}<0,01)$ - другої дослідної. Слід також відзначити тенденцію до збільшення на $0,6 \%$ (25\%) кількості Т-активних клітин у крові лошат української верхової породи першої дослідної групи та на 0,4\% (16,7\%) - другої дослідної.

Табличя 1

Вміст T-активних і T-термостабільних лімфоцитів у крові лошат, $\mathrm{M} \pm \mathbf{m}$

\begin{tabular}{|l|c|c|c|}
\hline \multirow{2}{*}{ Лімфоцити, \% } & \multicolumn{3}{|c|}{ Група } \\
\cline { 2 - 4 } & $\begin{array}{c}\text { контрольна } \\
(\mathrm{n}=5 / 5)\end{array}$ & $\begin{array}{c}\text { дослідна I } \\
(\mathrm{n}=4 / 6)\end{array}$ & $\begin{array}{c}\text { дослідна II } \\
(\mathrm{n}=6 / 4)\end{array}$ \\
\hline T-активні & $\frac{1,3 \pm 0,4}{2,4 \pm 0,2}$ & $\frac{3,0 \pm 0,1 * *}{3,0 \pm 0,3}$ & $\frac{2,7 \pm 0,2 * *}{2,8 \pm 0,5}$ \\
\hline T-термостабільні & $\frac{4,3 \pm 0,5}{3,8 \pm 0,4}$ & $\frac{4,0 \pm 0,1}{4,0 \pm 0,3}$ & $\underline{4,7 \pm 0,6}$ \\
\hline
\end{tabular}

Примітки: у чисельнику - чистокровна верхова, у знаменнику - українська верхова породи; $\mathrm{n}$ - кількість тварин кожної породи; ** - P < 0,01 у порівнянні з контрольною групою тварин

Встановлена тенденція до найбільш оптимального рівня Т-термостабільних лімфоцитів у крові лошат першої дослідної групи, який знаходився у межах 3 4\%. Збільшення кількості Т-термостабільних клітин вище 4\% свідчить про підвищення активності супресорної популяції Т-лімфоцитів, та пригнічення активності Т-хелперів, а відповідно і продукцію антитіл.

Отже, підсумовуючи результати досліджень стану клітинного імунітету лошат під впливом ріботану та циклоферону, можна зробити висновок про підвищення як клітинної активності Т-системи імунітету (загальна кількість Т-лімфоцитів), так і функціональної (Т-активні лімфоцити) під дією ріботану. 


\section{Висновки}

1. Під впливом ріботану у крові лошат підвищується клітинна (кількість Т-лімфоцитів на $0,4-2,3 \%$ ) та функціональна активність (Т-активні лімфоцити в 2,3 рази; $\mathrm{P}<0,05)$ Т-системи імунітету.

2. Під впливом циклоферону у крові лошат підвищується функціональна активність Т-системи імунітету (кількість Т-активних лімфоцитів на 16,7 $25 \% ; \mathrm{P}<0,05)$.

Перспективи подальших досліджень. На основі даних щодо стану клітинного імунітету лошат під впливом імуномодуляторів планується дослідження гуморальної ланки та оцінка показників росту і розвитку тварин.

\section{Бібліографічні посилання}

Ershov, F.I., Kiseljov, O.I. (2005). Interferony i ih induktory (ot molekul do lekarstv). M.: GJeOTAR-Media (in Russian).
Kacy, G.D., Kojuda, L.I. (2003). Metody ocenki zashhitnyh sistem organizma mlekopitajushhih. Lugansk: Jelton-2 (in Russian).

Kichun, I., Vishhur, O., Skorohid, I. (2001). Imunodeficiti $\mathrm{u}$ tvarin ta ihnja profilaktika. Tvarinnictvo Ukraini. 9-10, 18-19 (in Ukrainian).

Kojuda, L.I. (2000). Morfofunkcional'ni osoblivosti zahisnih sistem organizmu i produktivnist' hudobi chorno-rjaboï porodi pri adaptaciï v regioni Donbasu: Avtoref. dis... kand. biol. nauk: 03.00.13 Kiiv. nac. un-t im. T. Shevchenka (in Ukrainian).

Saliga, N., Vishhur, O. (2002). Formuvannja klitinnogo imunitetu porosjat pid vplivom imunomoduljatora timalinu. Visnik L'vivs'kogo universitetu. 29, 165-170 (in Ukrainian).

Стаття надійшла до редакиії 15.09.2016 